\title{
Compressive Strength of Post Fire Exposed Concrete Column Wrapped with Fiber Reinforced Polymer
}

\author{
Wardaya, D.A.S. ${ }^{1}$, Sugiharto, H. ${ }^{* *}$, and Pudjisuryadi, P. ${ }^{2}$
}

\begin{abstract}
In this study, behaviour of reinforced concrete columns strengthened using fiber reinforced polymer (FRP; glass fiber and carbon fiber) after fire exposure are discussed. After being exposed to fire as high as $720^{\circ} \mathrm{C}$ for 180 minutes, the specimens showed concrete and reinforcement strength degradation, even though there was no carbonation. It was found that specimens wrapped by carbon fiber showed better compressive strength but less ductility compared to specimens wrapped by glass fiber. It was also found that the low initial compressive strength did not decrease FRP confinement effectiveness. Increase of wrapped concrete compressive strength was evident despite the low initial strength $(<17 \mathrm{MPa})$. Strength estimation using ACI 440.2R-08 formula, which is originally for wrapped plain concrete without fire heat exposure, underestimated the compressive strength. In the proposed formula, the initial compressive strength $\left(\mathrm{f}_{\mathrm{co}}\right)$ should be adjusted by considering the modulus elasticity and strain limitation to have more precise estimation.
\end{abstract}

Keywords: Curing; fire exposed concrete column; fiber reinforced polymer.

\section{Introduction}

Research on the empirical formula for compressive strength estimation and behaviour of column confined using Fiber Reinforced Polymer (FRP) has been looked into extensively over the past two decades by many researchers. However most FRP confinement models [1-3] had been developed for FRP wrapped on concrete specimens with no exposure to fire. In Saafi's et al. model [1], variables which influence the FRP wrapped compressive strength are unconfined compressive strength, failure strains, and FRP stress-strain relationship. Saafi's et al. [1] research was conducted on concretefilled FRP tubes, tested under uniaxial compressive load with test variables include type of fiber, thickness of tube, and concrete compressive strength.

Lam and Teng [2] proposed simplified formula for concrete compressive strength with circular and square cross-section reinforced with FRP. The behavior of square concrete column wrapped with FRP is influenced by corner radius of the specimen [3]. There are different strains on the sides and the corners of the square cross-section [3].

\footnotetext{
1 Graduate Student, Department of Civil Engineering, Petra Christian University, J. Siwalankerto 121-131, Surabaya 60236, INDONESIA.

${ }^{2}$ Department of Civil Engineering, Petra Christian University, Jl. Siwalankerto 121-131, Surabaya 60236, INDONESIA.

*Corresponding author; Email: hands@petra.ac.id
}

Note: Discussion is expected before November, $1^{\text {st }} 2017$, and will be published in the "Civil Engineering Dimension", volume 20, number 1, March 2018.

Received 11 October 2016; revised 11 July 2017; accepted 17 August 2017.
Column size does not affect the strengthening behavior [3]. Lam and Teng [2] model was adopted by American Concrete Institute [4] as an empirical formula for FRP reinforcement design code.

FRP has also been used to strengthen post fire exposed concrete specimen [5]. Bisby et al. [5] suggested that the use of FRP in post fire exposed specimens would significantly increase (above $100 \%$ ) the compressive strength of the specimens. The model to estimate the compressive strength applies two assumptions: (1) the total increase in the ultimate stress is the same for the fire exposed and non-fire exposed concrete; and (2) the total increase in the ultimate axial strain between the strain at peak unconfined stress and the strain at peak FRPconfined stress is the same for the fire exposed and non-fire exposed concrete [5].

In this study, both concrete and reinforced concrete columns strengthened by FRP (glass fiber and carbon fiber) with two conditions (fire exposed and non-fire exposed) are presented. The effects of curing after exposure of fire were also investigated. An empirical formula for predicting FRP confined compressive strength of post fire exposure concrete column is proposed.

\section{Experimental Work}

\section{Materials}

The concrete mix proportion used for the research was composed of $410 \mathrm{~kg} / \mathrm{m}^{3}$ Portland Pozzolana Cement (PPC), $673.6 \mathrm{~kg} / \mathrm{m}^{3}$ sand, $1012.4 \mathrm{~kg} / \mathrm{m}^{3}$ crush stones, and $250 \mathrm{~kg} / \mathrm{m}^{3}$ water. The target compressive 
strength was $f_{c} 20 \mathrm{MPa}$. Concrete uniformity was controlled by w/c ratio of 0.6 , slump value with a range of $8-12 \mathrm{~cm}$, and also by Ultrasonic Pulse Velocity (UPV) test for 28 days concrete which resulted in deviation $\leq 5 \%$ [6]. Mild steel reinforcing bars with $4.4 \mathrm{~mm}$ diameter were used, both as longitudinal and transverse reinforcements. The tensile strength of reinforcements before (NF) and after fire exposure $(\mathrm{F})$ of the specimen was tested and presented in Table 1. The mechanical properties of FRP used in the experiment is shown in Table 2. Standard epoxy adhesive was used for FRP application. For fire heat exposed specimens, should there were any spalled concrete covers, repair work was done by using patching material.

Table 1. Reinforcement Tensile Test

\begin{tabular}{cccc}
\hline Code & Dia. $(\mathrm{mm})$ & Yield (MPa) & Ultimate $(\mathrm{MPa})$ \\
\hline $\mathrm{NF}$ & 4.4 & 466.37 & 526.24 \\
$\mathrm{~F}$ & 4.4 & 295.87 & 327.43 \\
\hline
\end{tabular}

Table 2. FRP Specification

\begin{tabular}{lcc}
\hline \multicolumn{1}{c}{ Property } & Carbon Fiber & Glass Fiber \\
\hline Tensile Strength & $834 \mathrm{MPa}$ & $460 \mathrm{MPa}$ \\
Tensile Modulus & $82 \mathrm{GPa}$ & $20.9 \mathrm{GPa}$ \\
Elongation at Break & $1 \%$ & $2.2 \%$ \\
Laminate Thickness & $1 \mathrm{~mm}$ & $1.3 \mathrm{~mm}$ \\
\hline
\end{tabular}

\section{Design and Test of Specimens}

The specimens used in this research were $100 \times 100$ x $300 \mathrm{~mm}^{3}$ columns (classified as short column with slenderness ratio of $10.39 \leq 22$ according to SNI 032847-2002 [7]). The longitudinal and transverse reinforcement used were $4-\varnothing 4.4 \mathrm{~mm}$ and $\varnothing 4.4 \mathrm{~mm}$ - $50 \mathrm{~mm}$, respectively (in accordance with SNI 032847-2002 [7]). The column detail is shown in Figure 1. The uniformity and quality of FRP application was done according to standards by TYFO (FRP applicator). To decrease ineffective area, the specimen corner was rounded $(r=10 \mathrm{~mm})$. FRP was applied fully to lateral area of the specimen. FRP application process is shown in Figure 2.

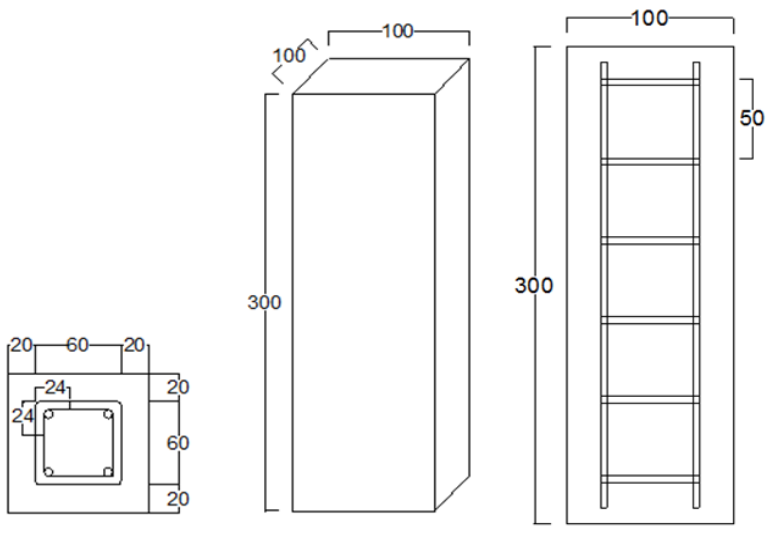

Figure 1. Column Dimensions and Detail
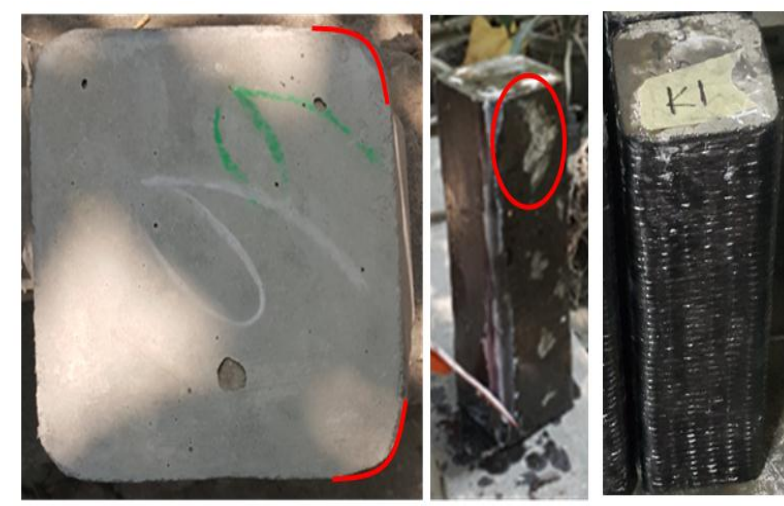

Figure 2. FRP Application Process

The specimen variables were reinforcement, fire exposure, curing after fire exposure, and wrapping material. The specimens were casted with and without reinforcement. Half of the specimens were exposed to fire at $720^{\circ} \mathrm{C}$ for 180 minutes in accordance to SNI 03-1736-2000 [8]. The fire exposure process uniformity was checked by carbonation test result. All fire heat exposed specimens showed the same color after tested by $1 \%$ phenolphthalein (PP), which means that all specimens experienced uniform combustion temperatures [6]. Some of the fire exposed specimens were cured using water for 3 days. Glass and carbon fibers were used for strengthening. With the mentioned variations, for easiness of identification, specimens' codes are listed as shown in Table 3.

Universal testing machine (UTM) was used to conduct the concentric compressive test. From the recorded specimen load resistance and displacement during the test, the axial stress-strain curve could be generated for each specimen.

\section{Test Result}

\section{Effect of Transverse Reinforcement and Fire Heat Exposure}

The test results show that concrete specimens (C$\mathrm{NF}$ ) and reinforced concrete specimens (RC-NF) have the same compressive strength. The compressive strength is shown in Figure 3. The same compressive strength showed that the transverse reinforcement had no effect. The distance between transverse reinforcement was $50 \mathrm{~mm}(\mathrm{H} / 2)$, so there was a concrete core that had no lateral confining pressure [7].

Figure 4 shows that concrete specimens exposed to high temperature at $720^{\circ} \mathrm{C}$ experienced strength degradation even though there was no carbonation process [6]. Curing treatment using water increased the compressive strength of fire exposed concrete [6]. 
Table 3. Specimens Code, Variation and Quantity

\begin{tabular}{|c|c|c|c|c|c|c|}
\hline No & Code & Type & Condition & Treatment & FRP & Quantity \\
\hline 1 & $\mathrm{~A}(\mathrm{C}-\mathrm{NF})$ & Concrete & Non- Fire Exposed & & & 6 \\
\hline 2 & C (RC-NF) & Reinforced Concrete & Non- Fire Exposed & & & 6 \\
\hline 3 & E (C-NF-G) & Concrete & Non- Fire Exposed & & Glass & 6 \\
\hline 4 & G (RC-NF-G) & Reinforced Concrete & Non- Fire Exposed & & Glass & 6 \\
\hline 5 & I (C-NF-C) & Concrete & Non- Fire Exposed & & Carbon & 6 \\
\hline 6 & K (RC-NF-C) & Reinforced Concrete & Non- Fire Exposed & & Carbon & 6 \\
\hline 7 & $\mathrm{~B}(\mathrm{C}-\mathrm{Fc})$ & Concrete & Fire Exposed & cured & & 3 \\
\hline 8 & $\mathrm{D}(\mathrm{RC}-\mathrm{Fc})$ & Reinforced Concrete & Fire Exposed & cured & & 3 \\
\hline 9 & $\mathrm{~F}(\mathrm{C}-\mathrm{Fc}-\mathrm{G})$ & Concrete & Fire Exposed & cured & Glass & 3 \\
\hline 10 & $\mathrm{H}$ (RC-Fc-G) & Reinforced Concrete & Fire Exposed & cured & Glass & 3 \\
\hline 11 & $\mathrm{~J}(\mathrm{C}-\mathrm{Fc}-\mathrm{C})$ & Concrete & Fire Exposed & cured & Carbon & 3 \\
\hline 12 & L (RC-Fc-C) & Reinforced Concrete & Fire Exposed & cured & Carbon & 3 \\
\hline 13 & $\mathrm{M}$ (C-Fnc) & Concrete & Fire Exposed & non-cured & & 3 \\
\hline 14 & N (RC-Fnc) & Reinforced Concrete & Fire Exposed & non-cured & & 3 \\
\hline 15 & $\mathrm{O}$ (C-Fnc-G) & Concrete & Fire Exposed & non-cured & Glass & 3 \\
\hline 16 & P (RC-Fnc-G) & Reinforced Concrete & Fire Exposed & non-cured & Glass & 3 \\
\hline 17 & $\mathrm{Q}$ (C-Fnc-C) & Concrete & Fire Exposed & non-cured & Carbon & 3 \\
\hline 18 & R (RC-Fnc-C) & Reinforced Concrete & Fire Exposed & non-cured & Carbon & 3 \\
\hline
\end{tabular}

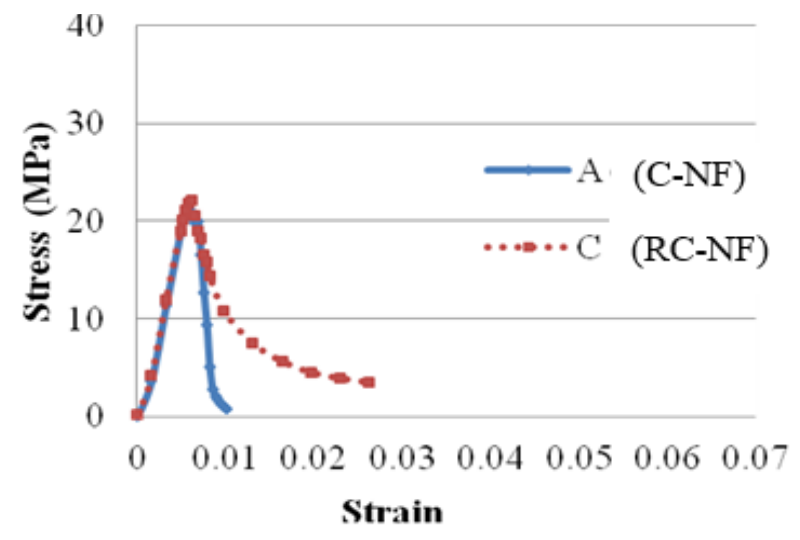

Figure 3. Stress-Strain Curve of Plain Concrete and Reinforced Concrete in Non-Fire Exposed Condition

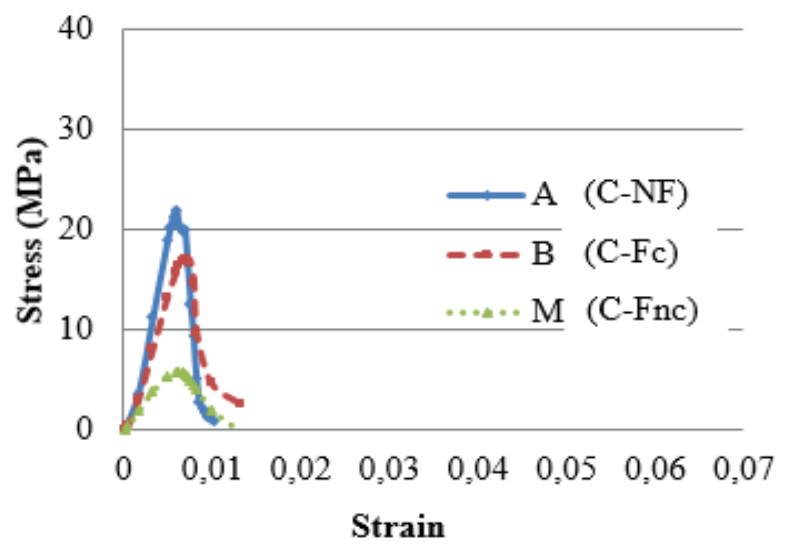

Figure 4. Stress-Strain Curve of Plain Concrete specimens in Non-Fire Exposed, Fire Exposed-Cured, and Fire Exposed Non-cured Conditions

\section{Specimens Confined by Fiber Reinforced Poly- mer}

The stress-strain curve of concrete specimens strengthen with FRP (glass fiber-carbon fiber) in
Non-Fire Exposed condition is shown in Figure 5. The stress-strain curve of reinforced concrete specimens strengthen with FRP (glass fiber-carbon fiber) in non-fire exposed condition is shown in Figure 6.

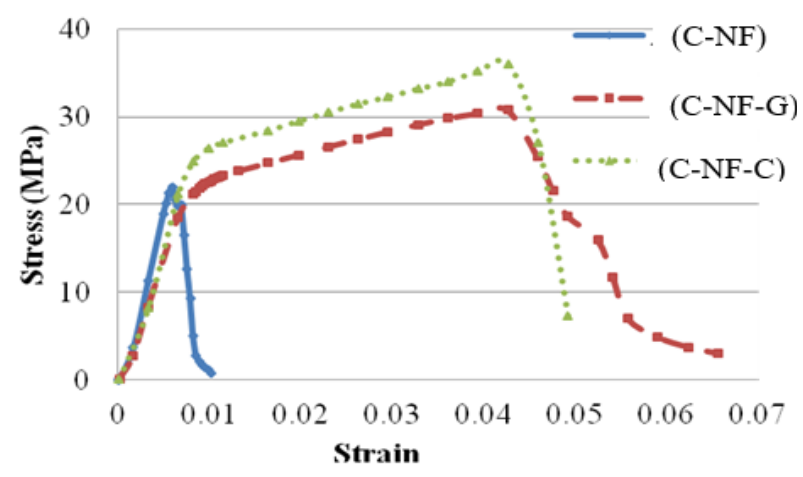

Figure 5. Stress-Strain Curve of Concrete Specimens Strengthen with FRP in Non-Fire Exposed Condition

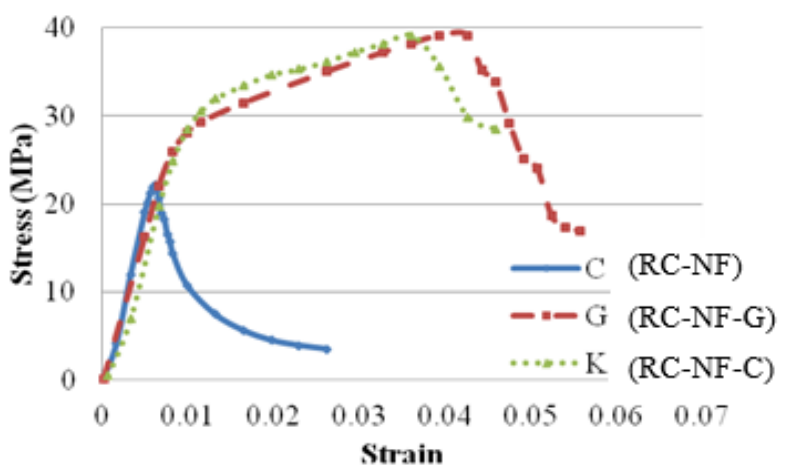

Figure 6. Stress-Strain Curve of Reinforced Concrete Specimens Strengthen with FRP in Non-fire Exposed Condition

The stress-strain curve of concrete specimens strengthen with FRP (glass fiber - carbon fiber) in fire exposed condition with curing treatment is shown in Figure 7. The stress-strain curve of reinforced 
concrete specimens strengthen with FRP (glass fiber - carbon fiber) in fire exposed condition with curing treatment is shown in Figure 8.

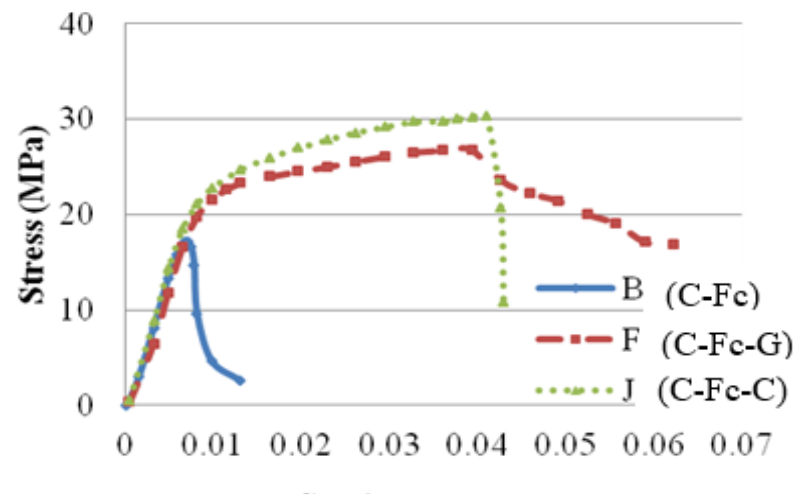

Strain

Figure 7. Stress-Strain Curve of Concrete Specimens Reinforced with FRP in Fire Exposed-cured Condition

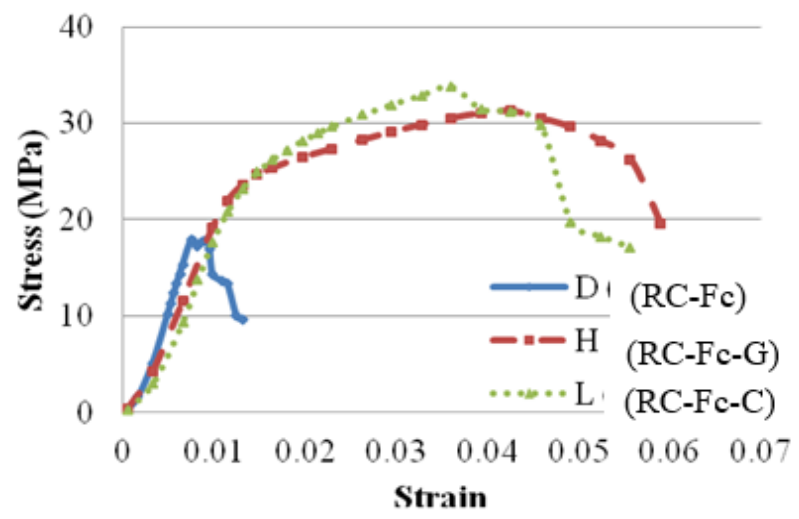

Figure 8. Stress-Strain Curve of Reinforced Concrete Specimens Reinforced with FRP in Fire Exposed-cured Condition

The stress-strain curve of concrete specimens strengthen with FRP (glass fiber and carbon fiber) in fire exposed condition without curing treatment is shown in Figure 9. The stress-strain curve of reinforced concrete specimens strengthen with FRP (glass fiber and carbon fiber) in fire exposed condition without curing treatment is shown in Figure 10.

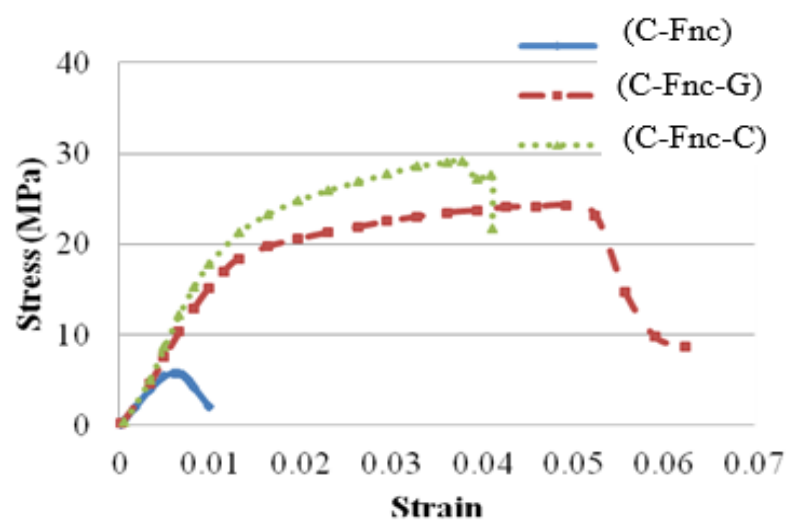

Figure 9. Stress-Strain Curve of Concrete Specimens Reinforced with FRP in Fire Exposed Non-Cured Condition

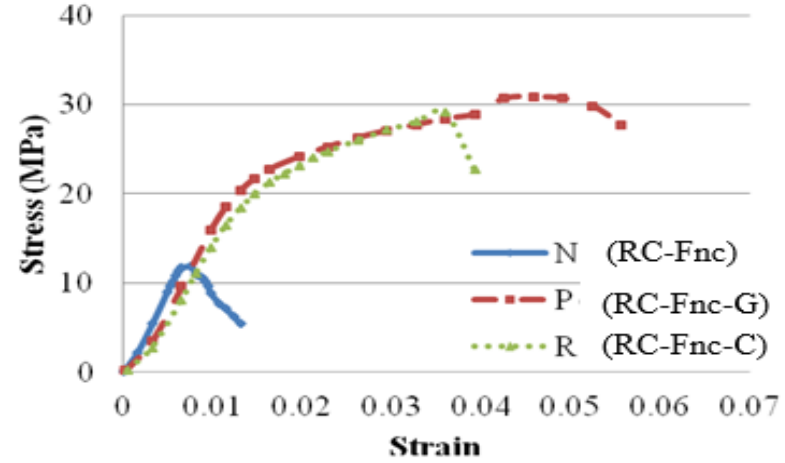

Figure 10. Stress-Strain Curve of Reinforced Concrete Specimens Reinforced with FRP in Fire Exposed NonCured Condition

Based on the stress-strain curve of all specimens variation, specimens strengthened by carbon fiber showed better compressive strength than specimens strengthened by glass fiber, but had more brittle failure mechanism. The low initial strength of specimens did not reduce the effectiveness of FRP confinement.

\section{Stress-Strain Model}

Lam and Teng [2] empirical model was used as reference in this study, because the model is used in ACI 440.2R-08 [4] for FRP design. In this study, it was found that stress strain curve of plain concrete strengthen with FRP (glass fiber-carbon fiber) in non-fire exposed condition was well predicted by the model. The model of plain concrete in non-fire exposed condition is shown by the straight dashed line and the experimental result is shown by the curve dotted line in Figure 11.

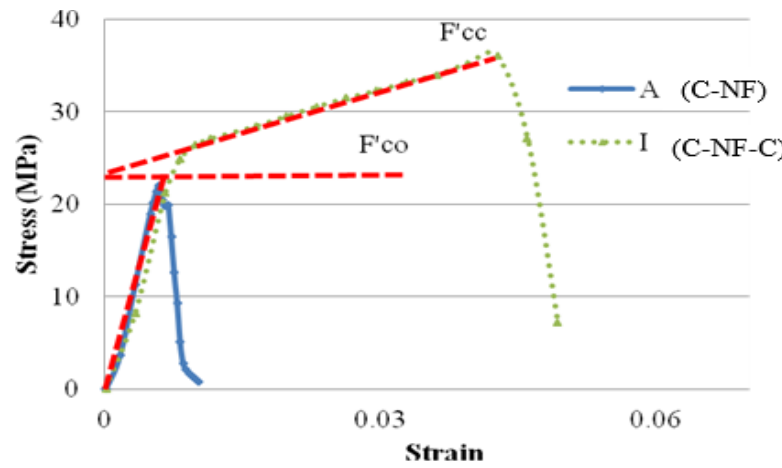

Figure 11. Stress-Strain Curve of Plain Concrete in NonFire Exposed Condition Reinforced with FRP

However, the ACI 440.2R-08 model cannot directly be applied to predict the stress-strain curve of reinforced concrete specimens and stress-strain curve of specimens in fire exposed condition with or without curing treatment. It was found that a slight modification in the model is necessary for stressstrain prediction of specimens with such conditions. The difference between ACI 400.2R-08 model and stress-strain experimental curve is shown in Figure 12. The gap of $\mathrm{f}_{\mathrm{cc}}$ was caused by different $\mathrm{f}_{\mathrm{c} \text {. }}$. 
For reinforced concrete specimens and specimens in fire exposed condition had difference elastic modulus with plain concrete in non-fire exposed condition. The difference of elastic modulus caused a "gap" between the initial specimen's compressive strength and the stress before the transition point. The gap caused the calculation based on ACI 440.2R-08 underestimate the compressive strength. The proposed model adjusted the $\mathbf{f}_{\text {co }}$ and is shown in Figure 13.

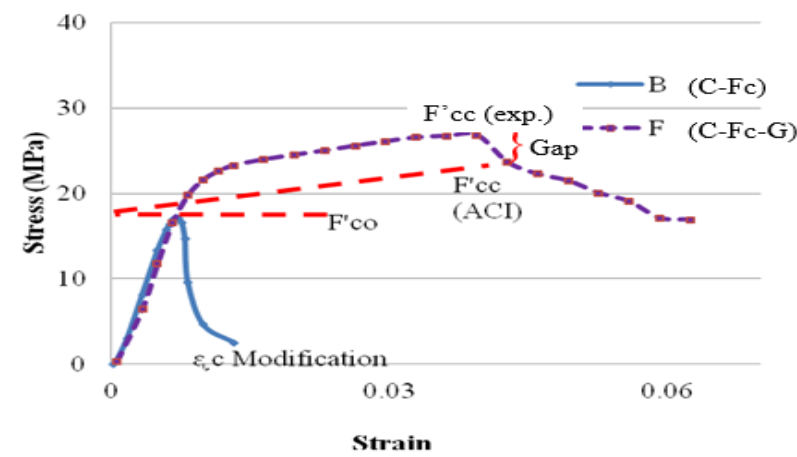

Figure 12. ACI Stress-Strain Curve Model for Reinforced Concrete Specimens and Specimens in Fire Exposed Condition

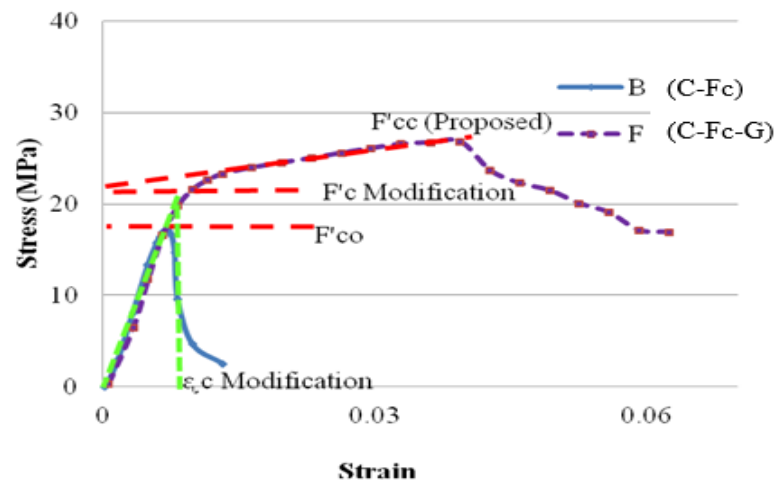

Figure 13. Proposed Stress-Strain Curve Model for Reinforced Concrete Specimens and Specimens in Fire Exposed Condition

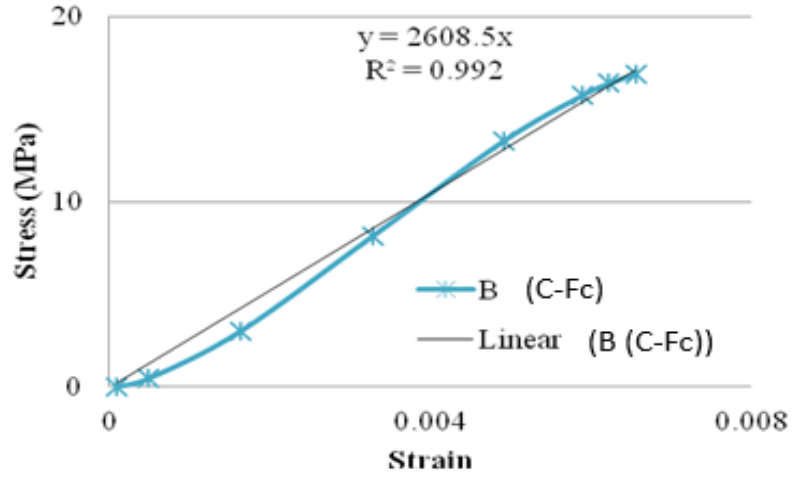

Figure 14. Fire exposed-Cured Plain Concrete Elastic Modulus Curve

To reduce the gap, modification on the $\mathrm{f}_{\text {co }}$ become $\mathrm{f}_{\mathrm{c}}$ modification is needed. $\mathrm{f}_{\mathrm{c}}$ modification is obtained from considering specimen's elastic modulus and the strain limitation. Specimen's elastic modulus was different for each variation. Example of Specimen's elastic modulus graph is shown in Figure 14. Specimen's elastic modulus and strain limitation for each variation are shown in Table 4.

Table 4. Strain Limitation of Reinforced Concrete Specimens and Fire Exposed Specimens

\begin{tabular}{lcrcc}
\hline $\begin{array}{c}\text { Specimen } \\
\text { Code }\end{array}$ & $\begin{array}{c}\mathrm{E} \\
(\mathrm{MPa})\end{array}$ & $\begin{array}{r}\mathrm{f}_{\mathrm{co}} \\
(\mathrm{MPa})\end{array}$ & $\begin{array}{c}\mathrm{f}_{\text {c modification }} \\
(\mathrm{MPa})\end{array}$ & $\begin{array}{c}\varepsilon_{\mathrm{c}} \\
\text { Modification }\end{array}$ \\
\hline $\mathrm{G}($ RC-NF-G) & 3714 & 22.16 & 30.71 & 0.0082 \\
K (RC-NF-C) & 3714 & 22.16 & 27.64 & 0.0074 \\
F (C-Fc-G) & 2608 & 17.16 & 18.81 & 0.0071 \\
H (RC-Fc-G) & 2166 & 17.78 & 22.85 & 0.0105 \\
J (C-Fc-C) & 2608 & 17.16 & 18.81 & 0.0071 \\
L (RC-Fc-C) & 2166 & 17.78 & 22.71 & 0.0104 \\
O (C-Fnc-G) & 1195 & 5.79 & 15.81 & 0.0131 \\
P (RC-Fnc-G) & 1751 & 11.84 & 22.12 & 0.0125 \\
Q (C-Fnc-C) & 1195 & 5.79 & 15.81 & 0.0131 \\
R (RC-Fnc-C) & 1751 & 11.84 & 16.79 & 0.0095 \\
\hline
\end{tabular}

Table 5. Comparison between ACI Model Estimation and Proposed Model Estimation

\begin{tabular}{|c|c|c|c|c|c|c|c|c|}
\hline No & $\begin{array}{l}\text { Specimen } \\
\text { Code }\end{array}$ & $\begin{array}{c}\text { Age } \\
\text { (days) }\end{array}$ & $\begin{array}{c}\text { Experimental } \\
\text { Strength (MPa) }\end{array}$ & $\begin{array}{c}\text { Strength } \\
\text { Enhancement (\%) }\end{array}$ & $\begin{array}{c}\text { ACI Model } \\
\text { Estimation (MPa) }\end{array}$ & $\begin{array}{c}\text { Error } \\
(\%)\end{array}$ & $\begin{array}{c}\text { Proposed Model } \\
\text { Estimation (Mpa) }\end{array}$ & $\begin{array}{c}\text { Error } \\
(\%)\end{array}$ \\
\hline 1 & $\mathrm{~A}(\mathrm{C}-\mathrm{NF})$ & 51 & 22.04 & \multirow{2}{*}{\multicolumn{5}{|c|}{ Control Specimen }} \\
\hline 2 & C (RC-NF) & 52 & 22.16 & & & & & \\
\hline 3 & E (C-NF-G) & 48 & 30.76 & $40 \%$ & 31.42 & $2.16 \%$ & 30.95 & $0.62 \%$ \\
\hline 4 & G (RC-NF-G) & 49 & 39.14 & $77 \%$ & 33.60 & $-14.16 \%$ & 39.58 & $1.12 \%$ \\
\hline 5 & I (C-NF-C) & 45 & 36.02 & $63 \%$ & 36.35 & $0.93 \%$ & 34.26 & $-4.89 \%$ \\
\hline 6 & K (RC-NF-C) & 43 & 39.14 & $77 \%$ & 38.49 & $-1.65 \%$ & 39.80 & $1.69 \%$ \\
\hline 7 & $\mathrm{~B}(\mathrm{C}-\mathrm{Fc})$ & 61 & $\begin{array}{l}17.16 \\
1778\end{array}$ & \multirow{2}{*}{\multicolumn{5}{|c|}{ Control Specimen }} \\
\hline 8 & D (RC-Fc) & 62 & $\begin{array}{l}17.78 \\
2681\end{array}$ & & & & & \\
\hline 9 & $\mathrm{~F}(\mathrm{C}-\mathrm{Fc}-\mathrm{G})$ & 60 & $\begin{array}{l}26.81 \\
31.27\end{array}$ & $\begin{array}{l}56 \% \\
76 \%\end{array}$ & $\begin{array}{l}22.59 \\
23.96\end{array}$ & $\begin{array}{l}-15.72 \% \\
-23.38 \%\end{array}$ & $\begin{array}{l}27.06 \\
31.07\end{array}$ & $\begin{array}{l}0.94 \% \\
-0.64 \%\end{array}$ \\
\hline 10 & H (RC-Fc-G) & 56 & $\begin{array}{l}31.27 \\
30.33\end{array}$ & $77 \%$ & 28.81 & $-5.02 \%$ & 30.13 & $\begin{array}{l}-0.64 \% \\
-0.66 \%\end{array}$ \\
\hline $\begin{array}{l}11 \\
12\end{array}$ & $\mathrm{~J}(\mathrm{C}-\mathrm{Fc}-\mathrm{C})$ & $\begin{array}{l}57 \\
54\end{array}$ & $\begin{array}{l}50.00 \\
33.75\end{array}$ & $90 \%$ & 30.12 & $-10.74 \%$ & 33.98 & $0.70 \%$ \\
\hline $\begin{array}{l}12 \\
13\end{array}$ & $\begin{array}{l}\mathrm{L}(\mathrm{RC}-\mathrm{Fc}-\mathrm{C}) \\
\mathrm{M} \text { (C-Fnc) }\end{array}$ & $\begin{array}{l}54 \\
61\end{array}$ & 5.79 & \multirow{2}{*}{\multicolumn{5}{|c|}{ Control Specimen }} \\
\hline 14 & $\mathrm{~N}$ (RC-Fnc) & 62 & 11.84 & & & & & \\
\hline 15 & $\mathrm{O}$ (C-Fnc-G) & 60 & 24.24 & $319 \%$ & 11.13 & $-54.10 \%$ & 24.81 & $2.33 \%$ \\
\hline 16 & P (RC-Fnc-G) & 56 & 30.85 & $161 \%$ & 12.55 & $-59.32 \%$ & 31.08 & $0.74 \%$ \\
\hline 17 & Q (C-Fnc-C) & 57 & 29.22 & $404 \%$ & 17.34 & $-40.66 \%$ & 28.15 & $-3.65 \%$ \\
\hline 18 & R (RC-Fnc-C) & 54 & 28.88 & $144 \%$ & 18.71 & $-35.20 \%$ & 29.08 & $0.71 \%$ \\
\hline
\end{tabular}


The proposed model is more precise than the ACI 440.2R-08 model. In other word, the estimation is more efficient. The comparison between the ACI model estimation and proposed model estimation is shown in Table 5.

Proposed flow chart calculations of column strengthen by FRP various conditions are shown in Figure 15. For axial capacity design, shear strength safety factor (0.65) needs to be used because the increased compressive strength was the effect of FRP confinement.

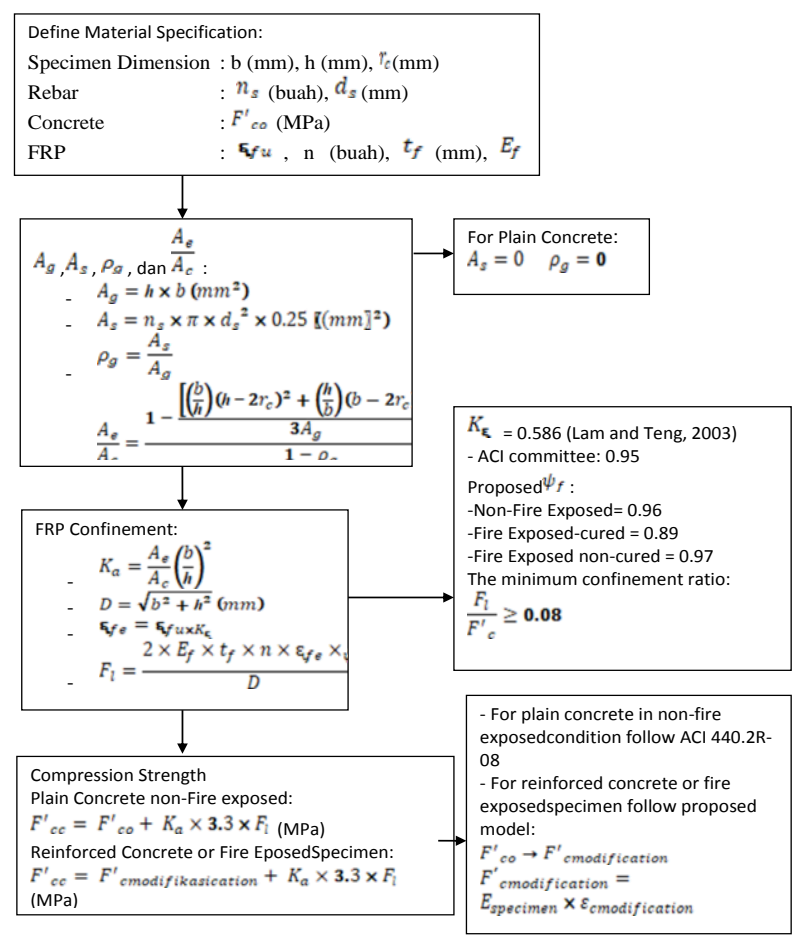

Figure 15. Compression Strength Calculation Flow Chart for Rectangular Column Confined by FRP

\section{Conclusion}

In this paper, ACI 440.2R-08 model has been evaluated and reviewed, using test on plain concrete specimens and reinforced concrete specimens in various condition (non-fire exposed, fire exposedcured, and fire exposed non-cured). Based on the test results of the study, the following conclusions can be drawn:

1. Specimens strengthen by carbon fiber showed better compressive strength than specimens strengthen by glass fiber but had more brittle pattern.

2. Specimens in fire exposed condition with or without curing process has low initial compressive strength $(<17 \mathrm{MPa})$ and various collapse pattern, but it did not reduce FRP confinement effectiveness. The compressive strength of specimens with low initial compressive strength strengthens by FRP was significantly increased (Figures 7-10).
3. Estimation of compressive strength using ACI 440.2R-08 model is appropriate for plain concrete specimens in non-fire exposed condition (Figure 11).

4. Reinforced concrete, fire exposed concrete, and fire exposed reinforced concrete had different elastic modulus with non fire exposed concrete. Gap between specimen's initial strength and the transition point was caused by the difference elastic modulus. The compressive strength was underestimated by ACI 440.2R-08 model (Figure 12).

5. For efficiency, modification (Figure 13) on the $\mathrm{f}_{\mathrm{co}}$

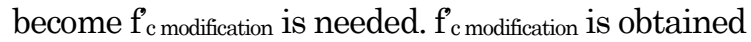
by considering specimen's elastic modulus and the strain limitation ( $\varepsilon_{c}$ modification).

6. Proposed model generates closer compressive strength estimation to the compressive test result, with maximum error $-4.89 \%$ for all specimens (Table 5).

\section{References}

1. Saafi, M., Toutanji H., and Li, Z., Behavior of Concrete Columns Confined with Fiber Reinforced Polymer Tubes, ACI Materials Journal, 96(4), 1999, pp. 500-509.

2. Lam, L. and Teng, J.G., Design-oriented StressStrain Model, Journal of Reinforced Plastics and Composites, 22(13), 2003, pp. 1149-1186.

3. Lee, C.S., Hegemier, G.A., and Phillippi, D.J., Analytical Model for Fiber-Reinforced PolymerJacketed Square Concrete Columns in Axial Compression, ACI Structural Journal, 107(2), 2010, pp. 208-217.

4. ACI 440.2R-08, Guide for the Design and Construction of Externally Bonded FRP Systems for Strengthening Concrete Structures, American Concrete Institute, 2008.

5. Bisby, L.A., Chen, J.F., Li, S.Q., Stratford, T.J., Cueva, N., and Crossling, K., Strengthening FireDamaged Concrete by Confinement with FiberReinforced Polymer Wraps, Engineering Structures, 33(12), 2011, pp. 3381-3391.

6. Wardaya, D.A.S., Analisa Rumus Empiris Kuat Tekan Kolom dengan Penggunaan Fiber Reinforced Polymer pada Kondisi: Non-Fire exposed, Fire exposed-Curing, dan Fire exposed Non-Curing, Unpublished Graduate Theses, Petra Christian University, 2016.

7. Badan Standarisasi Nasional, SNI 03-2847-2002: Tata Cara Perhitungan Struktur Beton Untuk Bangunan Gedung, 2002.

8. Badan Standarisasi Nasional, SNI 03-1736-2000: Tata Cara Perencanaan Sistem Proteksi Pasif Untuk Pencegahan Bahaya Kebakaran pada Bangunan Rumah dan Gedung, 2000. 